Open Journal of Gastroenterology and Hepatology
(ISSN:2637-4986)

\title{
Study of the effect of sofosbuvir and daklatasivir on respiratory system in patients with chronic hepatitis $\mathbf{C}$
}

\author{
Alaa Aboud', Laila anwer², Mohammed soliman ${ }^{3}$ \\ ${ }^{1}$ Department of Tropical Medicine, Beni-Suef University Faculty of Medicine, Benisuef 62511, Egypt; \\ ${ }^{2}$ Department of Chest, Beni-Suef University Faculty of Medicine; ${ }^{3}$ Department of radiology,Beni \\ suef university faculty of medicine
}

\section{ABSTRACT}

Back ground: The aim is to study effect of sofosbuvir and daklatasivir on respiratory system.

*Correspondence to Author:

Alaa Aboud

Department of Tropical Medicine,

Patient and methods : A randomized study was done after all Beni-Suef University Faculty of patients gave an informed consent before the start. The study Medicine, Benisuef 62511, Egypt population consists of 21 patients receiving treatment of $\mathrm{HCV}$ coming to the outpatient clinic of beni suef university hospital.

How to cite this article:

Results : There is no major adverse effect of sofosbuvir and Alaa Aboud, Laila anwer, Mohamdaklatasivir on respiratory system as proved by assessment of pulmonary function and Computed tomography before and after treatment.

med soliman.Study of the effect of sofosbuvir and daklatasivir on respiratory system in patients with chronic hepatitis $\mathrm{C}$. Open Journal of

Keywords: Hepatitis C- DAAs - Chest. Gastroenterology and Hepatology, 2019, 2:11

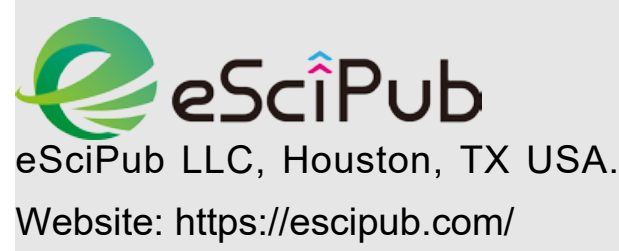




\section{Introduction}

$\mathrm{HCV}$ is considered a major health issue in Egypt because of high prevalence as declared by demographic health survey of 2008 that showed a national seroprevalence of $14.7 \%$ among those aged between 15 and 59 years, with viremic prevalence of $9.7 \%$ in this age group that increased with age and was higher in males than in females in all age groups studied.(Waked et al., 2017)

It is considered major cause of chronic liver disease and has been recognized as a global health problem due to progression into cirrhosis, liver cell failure and HCC, also about 170 million people in world are diseased with HCV and 60 to $80 \%$ goes into chronic infection ( AA Modi and TJ Liang 2008)

The new direct acting antiviral agents has proved high efficacy in treatment of $\mathrm{HCV}$ and so provide promising solution for possibility of $\mathrm{HCV}$ eradication, the most important corner stone drug is sofosbuvir (sovaldi).

Sofosbuvir is a nucleotide analog that is a highly potent inhibitor of theNS5B polymerase in HCV. This drug has shown high efficacy in combination with several other drugs with and without PEG-INF, against HCV,it is of special interest among the directly acting antiviral drugs under development, due to its high potency, low side effects, oral administration, and high barrier to resistance, it acts by inhibition of NS5B which is one of the non-structural proteins that is essential for HCV RNA replication.(Harmeet etal.,2014)

Daclalatasvir is also one of the efficient DAAs, it is NS5A inhibitor that is effective against all HCV genotypes with pangenotypic activity, single dosing and is well tolerated and is used in combination with sofosbuvir for prevention of emergence of resistance (osamaetal., 2018)

Interferon was associated with various respiratory complications ranging from mid interstitial pneumonitis to severe acute respiratory distress syndrome up to death and also sarcoid like reactions, bronchiolitis obliterans and asthma exacerbation but New DAAs respiratory effects is not well evaluated.(Dina etal.,2017)

Patients and methods

A randomized study was done after all patients were given an informed consent before the start. The study population consists of 21 patients already receiving treatment of $\mathrm{HCV}$.

Aim of this work is to observe effect of DAAs treatment on respiratory system.

\section{Inclusion criteria:}

Patients aged $>18$ years old .

Patients with compensated Liver disease

Exclusion criteria:

Ascites.

Malignancy

End stage organ failure.

All patients were subjected to history taking , clinical examination .

- Abdominal Examination (hepatomegaly, splenomegaly, ascites ) .

- Chest Examination

Laboratory investigations including:

Liver synthetic function, AFP,complete blood picture and creatinine.

\section{HCV RNA by PCR.}

Liver profile was assessed before, during and after end of treatment.

Imaging in the form of :

abdominal ultrasonography

CT Chest before and after end of treatment

Pulmonary function test before and after end of treatment

\section{Results}

In table (1) ages of the patients range from 36 to 72 years with mean age 53 years, $71 \%$ of patients were male and $28 \%$ of patients were females, $42 \%$ of patients were smokers and the major risk of transmission of HCV infection was antischistosomal injections in $42.9 \%$, Previous operations was a risk in $28.6 \%$ and there was no obvious risk in $28.6 \%$. 
In table(2) there was no symptoms suggestive of In table (3) there was no significant changes in decompensated liver disease, by abdominal pulmonary functions and imaging in studied examination there was hepatomegaly in $42.9 \%$ patients before and after treatment.

and in $71.4 \%$ on ultrasonography. There was In table 4 fatiguability was the most frequent splenomegaly in $33.3 \%$ on ultrasonography. draw back and to less ex-tent GIT toubles, cough and pruritus in about $4.8 \%$ of patients.

Table (1): Demographic data of studied patients

\begin{tabular}{|c|c|c|}
\hline & Total $(n=21)$ & $\%$ \\
\hline $\begin{array}{l}\text { Age (Year) } \\
\text { Range } \\
\text { Mean } \pm S D\end{array}$ & $\begin{array}{l}36-72 \\
53.7 \pm 10.9\end{array}$ & - \\
\hline $\begin{array}{l}\text { Sex } \\
\text { Male } \\
\text { Female }\end{array}$ & $\begin{array}{l}15 \\
6\end{array}$ & $\begin{array}{l}71.4 \\
28.6 \\
\end{array}$ \\
\hline Smoking & 9 & 42.9 \\
\hline $\begin{array}{l}\text { Risk factors } \\
\text { No risk } \\
\text { Antischistosomal injections } \\
\text { Operation }\end{array}$ & $\begin{array}{l}6 \\
9 \\
6\end{array}$ & $\begin{array}{l}28.6 \\
42.9 \\
28.6\end{array}$ \\
\hline
\end{tabular}

Table (2) Clinical and sonographic data of studied patients.

\begin{tabular}{|l|l|l|}
\hline & Total (n=21) & $\%$ \\
\hline Bleeding tendency & 0 & 0 \\
\hline Hematemesis & 0 & 0 \\
\hline Jaundice & 0 & 0 \\
\hline Hepaic encephalopathy & 0 & 0 \\
\hline Liver by exam & 9 & 42.9 \\
\hline Spleen by exam & 0 & 0 \\
\hline Ascites by exam & 0 & 0 \\
\hline Liver sonar & 15 & 71.4 \\
\hline Spleen by sonar & 7 & 33.3 \\
\hline Ascites by sonar & 0 & 0 \\
\hline
\end{tabular}

Table (3): Comparison between pulmonary function test and CT chest of the studied patients before and after treatment

\begin{tabular}{|l|l|l|l|}
\hline & Pre & Post & P value \\
\hline FVE1 & & & \\
Range & $71-107$ & $72-109$ & 0.934 \\
Mean \pm SD & $89.1 \pm 10.9$ & $89.2 \pm 10.2$ & \\
\hline FVC & & & \\
Range & $66-122$ & $67-124$ & 0.157 \\
Mean \pm SD & $90.2 \pm 13.7$ & $87.4 \pm 13.5$ & \\
\hline FEV1/FVC & $64-92$ & $55-95$ & 0.734 \\
Range & $77.8 \pm 6.9$ & $77.3 \pm 8.2$ & \\
Mean $\pm S D$ & $200-420$ & $210-430$ & 0.682 \\
\hline 6mw & $347.6 \pm 67.9$ & $350.6 \pm 62.6$ & \\
Range & & & \\
Mean $\pm S D$ & $96-99$ & $96-99$ & 0.261 \\
\hline Spo 2 & $97.3 \pm 0.9$ & $97.6 \pm 0.9$ & \\
Range & 0 & 0 & \\
Mean $\pm S D$ & & & \\
\hline ct chest & & & \\
\hline
\end{tabular}


Table (4): Assessment of side effects of treatment in the studied patients

\begin{tabular}{|l|l|l|l|l|}
\hline Side Effect & $\begin{array}{l}\mathbf{4} \text { week } \\
\text { No.(\%) }\end{array}$ & $\begin{array}{l}\mathbf{8} \text { week } \\
\text { No.(\%) }\end{array}$ & $\begin{array}{l}\text { 12 week } \\
\text { No.(\%) }\end{array}$ & \multirow{2}{*}{ P value } \\
\hline No side effects & $11(52.4)$ & $8(38.1)$ & $9(42.9)$ & \\
\cline { 1 - 4 } Fatigue & $8(38.1)$ & $11(52.4)$ & $10(47.6)$ & \multirow{3}{*}{0.858} \\
\hline GIT Troubles & $1(4.8)$ & $1(4.8)$ & $0(0)$ & \\
\hline Cough & $1(4.8)$ & $1(4.8)$ & $1(4.8)$ & \\
\hline Pruritus & $0(0)$ & $0(0)$ & $1(4.8)$ & \\
\hline
\end{tabular}

Table (5): Comparison between the laboratory data of studied patients during different follow up period

\begin{tabular}{|c|c|c|c|c|}
\hline & \multicolumn{4}{|l|}{ Time (week) } \\
\hline & Before & 4 week & 8 week & 12 week \\
\hline $\begin{array}{l}\text { ALT } \\
\text { Range } \\
\text { Mean } \pm S D\end{array}$ & $\begin{array}{l}22-85 \\
48.5 \pm 17.9\end{array}$ & $\begin{array}{l}10-54 \\
30.1 \pm 13.0^{*}\end{array}$ & $\begin{array}{l}11-33 \\
23.8 \pm 7.3^{*+}\end{array}$ & $\begin{array}{l}11-30 \\
19.5 \pm 6.1^{\star+\#}\end{array}$ \\
\hline $\begin{array}{l}\text { AST } \\
\text { Range } \\
\text { Mean } \pm S D\end{array}$ & $\begin{array}{l}19-88 \\
51.0 \pm 19.6\end{array}$ & $\begin{array}{l}10-55 \\
29.0 \pm 13.2^{*}\end{array}$ & $\begin{array}{l}10-36 \\
23.5 \pm 7.7^{\star+}\end{array}$ & $\begin{array}{l}9-30 \\
18.2 \pm 5.8^{\star+\#}\end{array}$ \\
\hline $\begin{array}{l}\text { HB } \\
\text { Range } \\
\text { Mean } \pm S D\end{array}$ & $\begin{array}{l}12-16.6 \\
14.3 \pm 1.4\end{array}$ & $\begin{array}{l}11-16 \\
13.8 \pm 1.4^{*}\end{array}$ & $\begin{array}{l}11-15 \\
13.0 \pm 1.3^{*+}\end{array}$ & $\begin{array}{l}10.9-15 \\
12.8 \pm 1.4^{*+}\end{array}$ \\
\hline $\begin{array}{l}\text { Bilirubin } \\
\text { Range } \\
\text { Mean } \pm S D\end{array}$ & $\begin{array}{l}0.5-1.1 \\
0.7 \pm 0.2\end{array}$ & $\begin{array}{l}0.5-0.9 \\
0.7 \pm 0.1\end{array}$ & $\begin{array}{l}0.36-0.9 \\
0.6 \pm 0.1\end{array}$ & $\begin{array}{l}0.4-0.9 \\
0.6 \pm 0.1\end{array}$ \\
\hline $\begin{array}{l}\text { Albumin } \\
\text { Range } \\
\text { Mean } \pm S D\end{array}$ & $\begin{array}{l}3.7-4.9 \\
4.4 \pm 0.4\end{array}$ & $\begin{array}{l}3.5-4.8 \\
4.2 \pm 0.3 \\
\end{array}$ & $\begin{array}{l}4-4.9 \\
4.2 \pm 0.3 \\
\end{array}$ & $\begin{array}{l}3.7-4.6 \\
4.2 \pm 0.2 \\
\end{array}$ \\
\hline $\begin{array}{l}\text { PT } \\
\text { Range } \\
\text { Mean } \pm S D\end{array}$ & $\begin{array}{l}11-13 \\
12.1 \pm 0.8\end{array}$ & $\begin{array}{l}11-13 \\
12.0 \pm 0.7\end{array}$ & $\begin{array}{l}11-13 \\
12.1 \pm 0.8\end{array}$ & $\begin{array}{l}11-13 \\
12.1 \pm 0.8\end{array}$ \\
\hline $\begin{array}{l}\text { Creatinine } \\
\text { Range } \\
\text { Mean } \pm S D\end{array}$ & $\begin{array}{l}0.7-1.1 \\
0.9 \pm 0.1\end{array}$ & $\begin{array}{l}0.5-1 \\
0.8 \pm 0.1\end{array}$ & $\begin{array}{l}0.5-1 \\
0.8 \pm 0.1\end{array}$ & $\begin{array}{l}0.5-1 \\
0.7 \pm 0.2\end{array}$ \\
\hline $\begin{array}{l}\text { AFP } \\
\text { Range } \\
\text { Mean } \pm S D\end{array}$ & $\begin{array}{l}1.4-12.2 \\
5.7 \pm 3.5\end{array}$ & 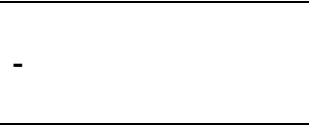 & - & $\begin{array}{l}1.5-15 \\
5.5 \pm 3.6\end{array}$ \\
\hline $\begin{array}{l}\text { TLC } \\
\text { Range } \\
\text { Mean } \pm S D\end{array}$ & $\begin{array}{l}4300-8900 \\
6742.9 \pm 1479.4\end{array}$ & $\begin{array}{l}4600-10000 \\
6585.7 \pm 1584.7\end{array}$ & $\begin{array}{l}4700-8300 \\
6033.3 \pm 1092.4\end{array}$ & $\begin{array}{l}4700-9000 \\
6176.2 \pm 1317.5\end{array}$ \\
\hline $\begin{array}{l}\text { PLT } \\
\text { Range } \\
\text { Mean } \pm S D\end{array}$ & $\begin{array}{l}150000-350000 \\
239047.6 \pm 60441.3\end{array}$ & $\begin{array}{l}164000-432000 \\
235761.9 \pm 64027.3\end{array}$ & $\begin{array}{l}154000-316000 \\
210952.4 \pm 44894.9\end{array}$ & $\begin{array}{l}150000-265000 \\
196714.3 \pm 30537.1\end{array}$ \\
\hline
\end{tabular}

In table 5 there was no significant change in Bilirubin, PT ,albumin , creatinine, WBC count platelets count and AFP during different weeks of treatment.There was significant decrease of hemoglobin when compared before treatment and during different weeks of follow up.
There was significant normalization of liver enzymes when compared before treatment and during different weeks of follow up.

In table 6 SVR was $90.4 \%$ non-responder was $4.8 \%$ and relapse was $4.8 \%$.

Table (6) Assessment of efficacy of treatment

\begin{tabular}{|l|l|l|l|}
\hline Total $(\mathbf{n}=21)$ & SVR & Non responsive & Relapse \\
\hline HCV, no. $(\%)$ & $19(90.4)$ & $1(4.8)$ & $1(4.8)$ \\
\hline
\end{tabular}


Alaa Aboud et al., OJGH, 2019 2:11

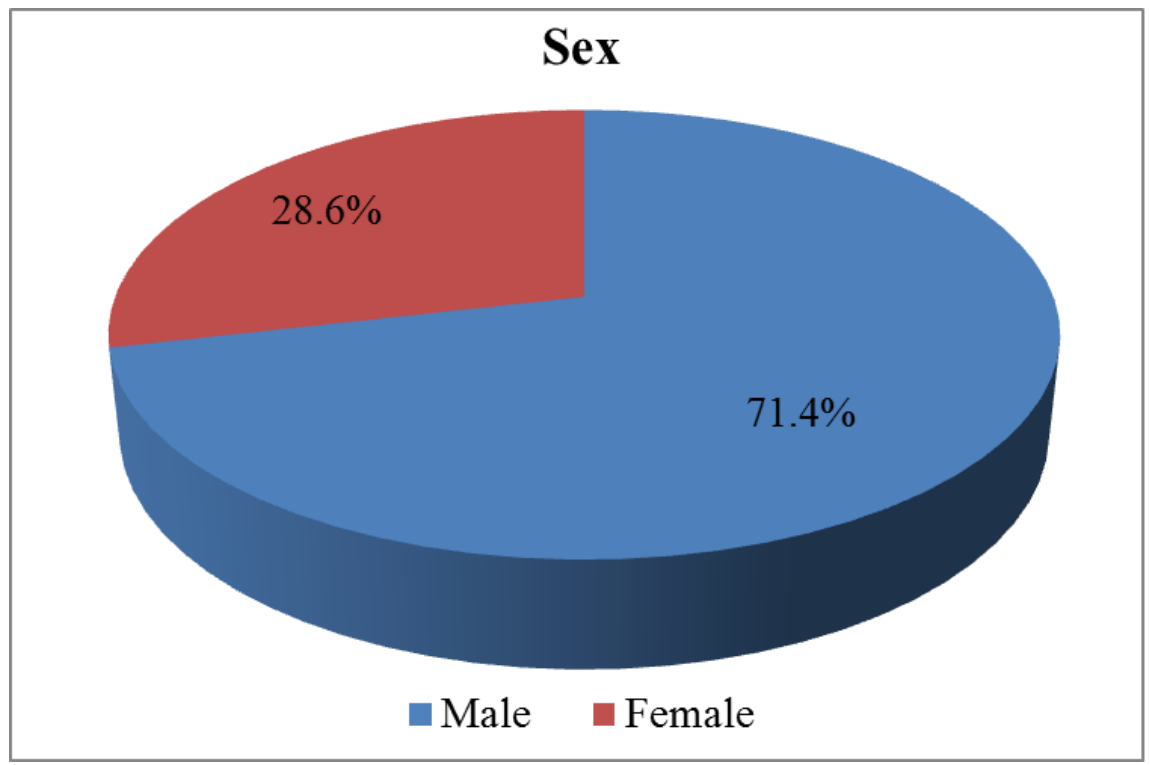

Figure 1a) Sex of the studied patients.

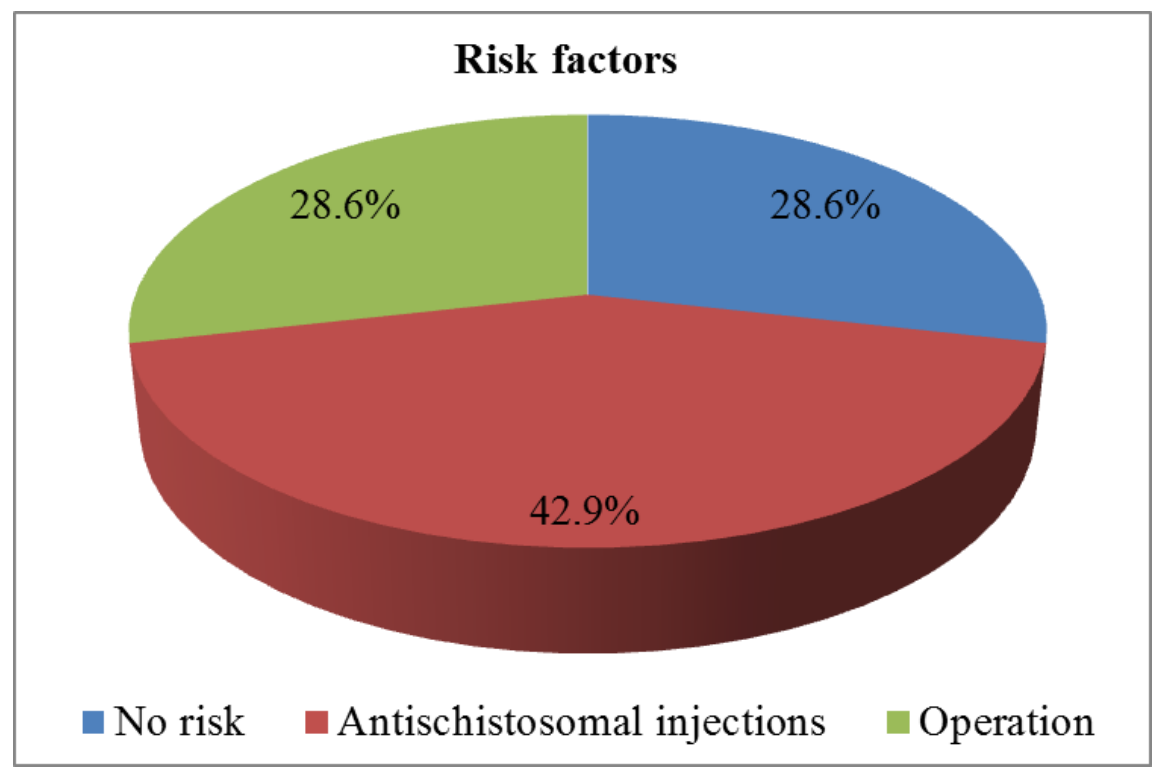

Figure 1b) Risk factors of HCV infection.

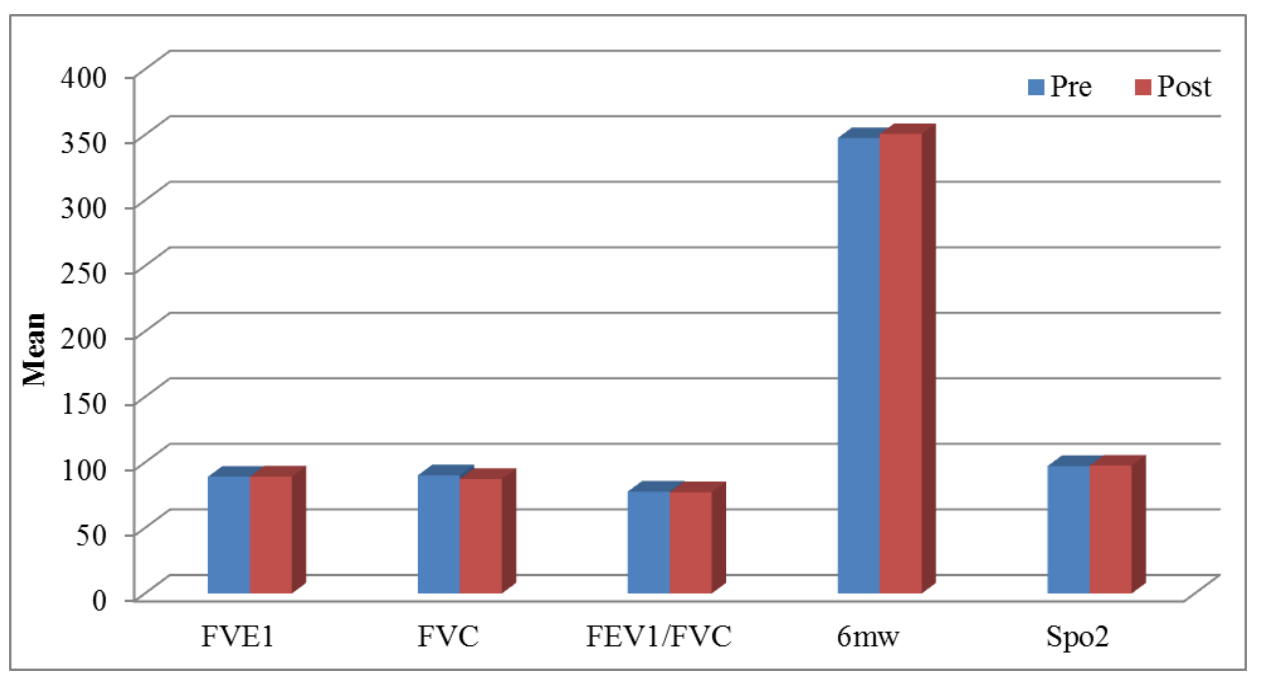

Figure2) Comparison between pulmonary functions before and after treatment 


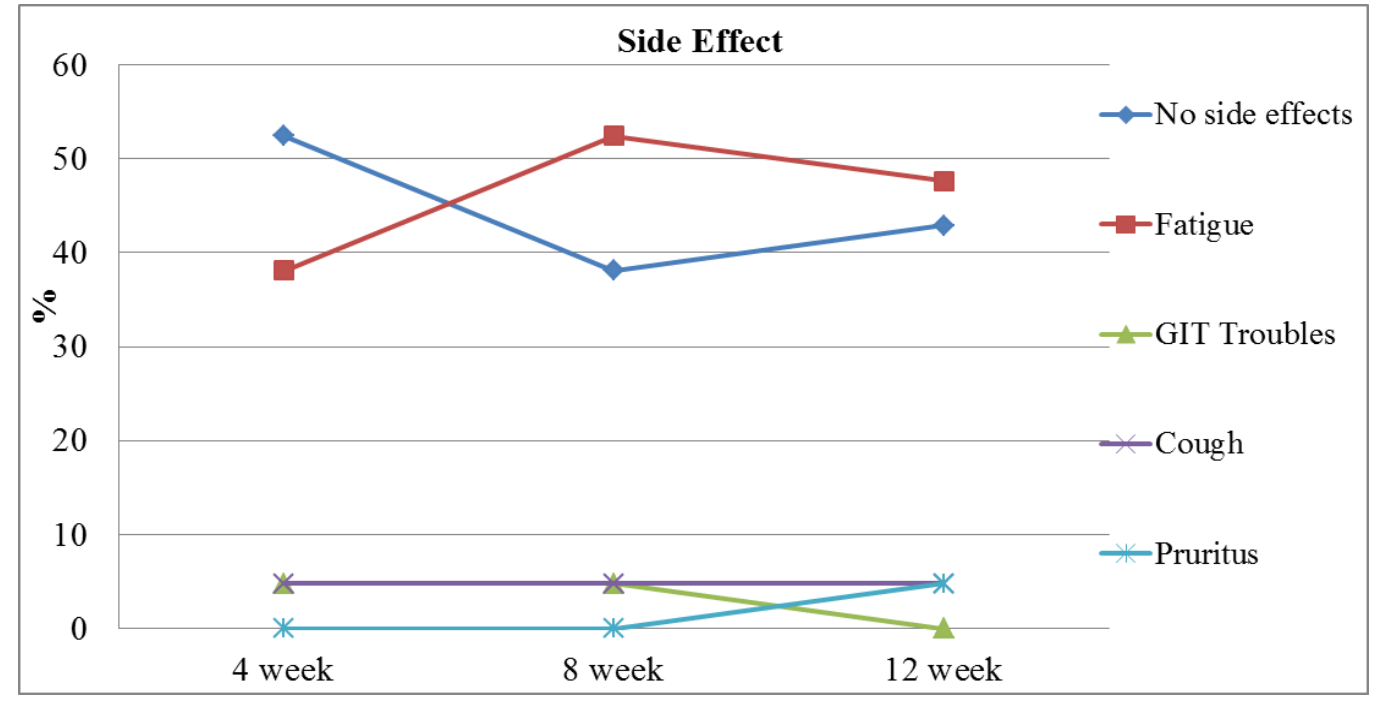

Figure 3) Assessment of side effects of treatment in the studied patients

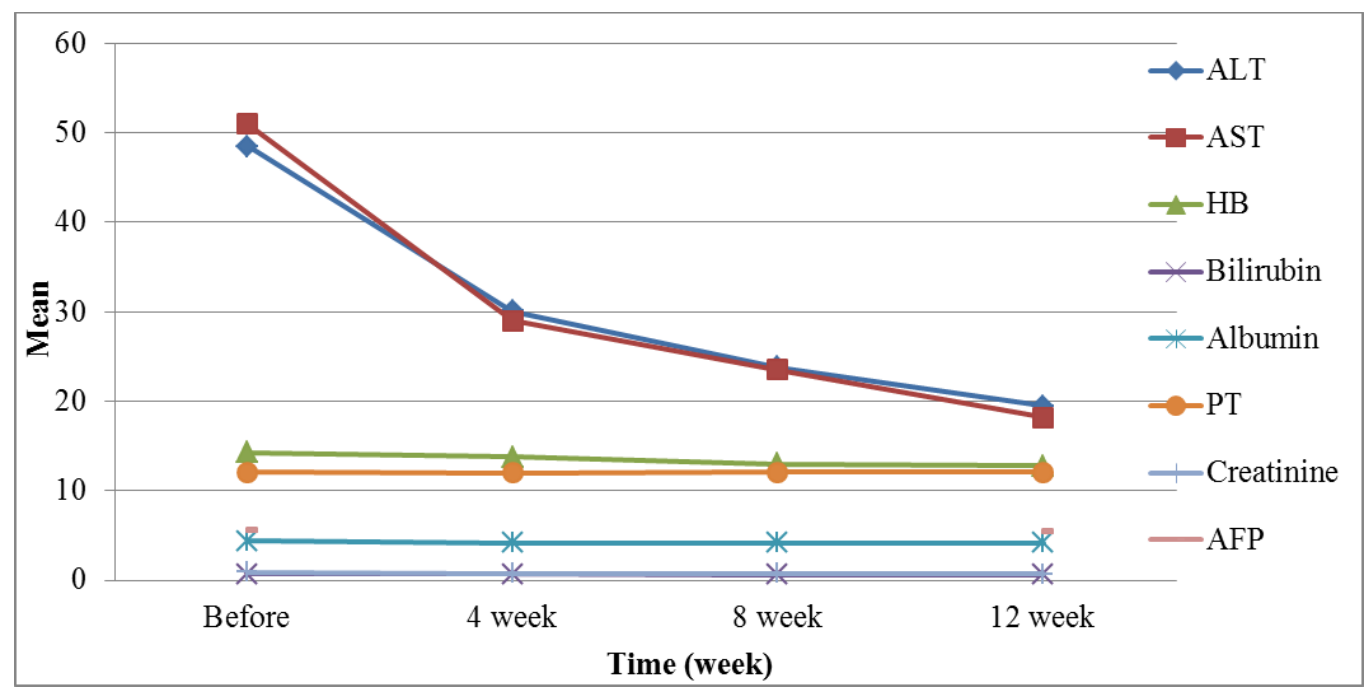

Figure (4a): Assessment of laboratory parameters of studied patients dur-ing different follow up period

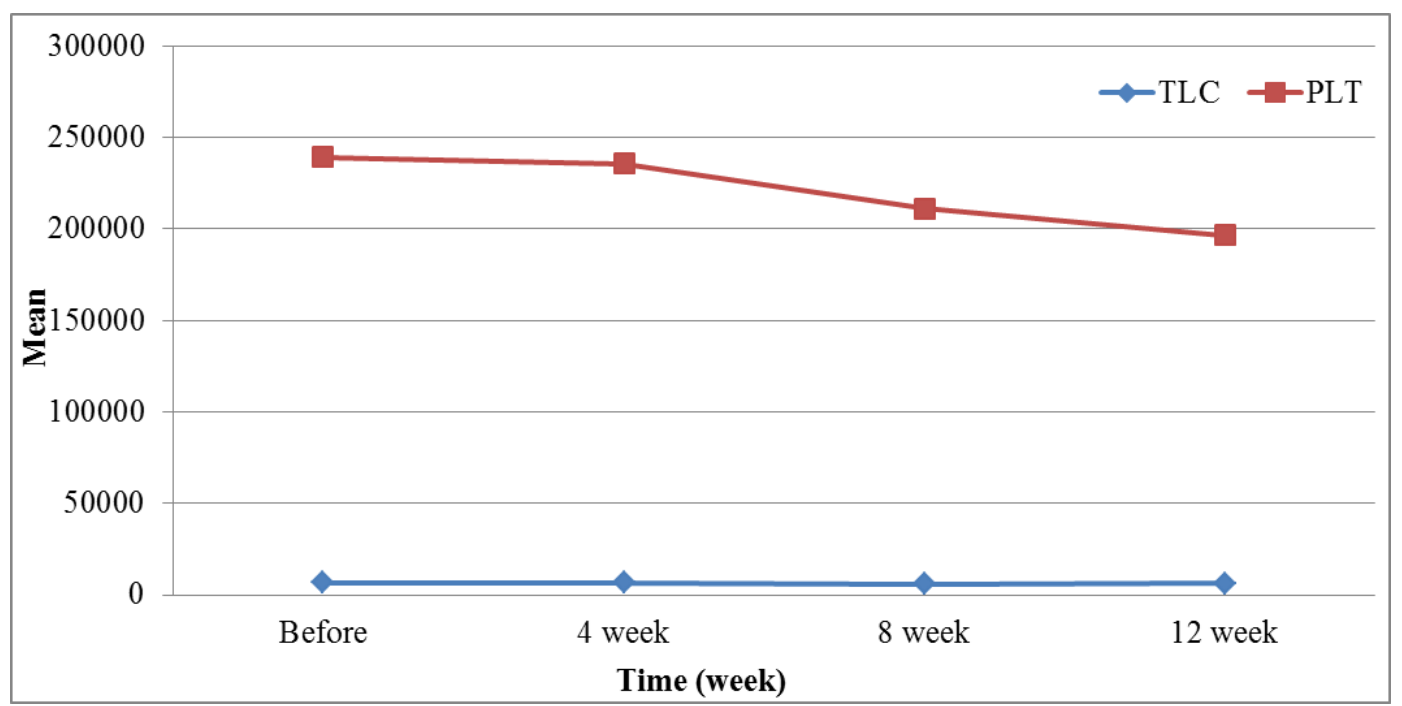

Figure (4b): Assessment of Total leucocytic count and platelets count of studied patients during different follow up period 


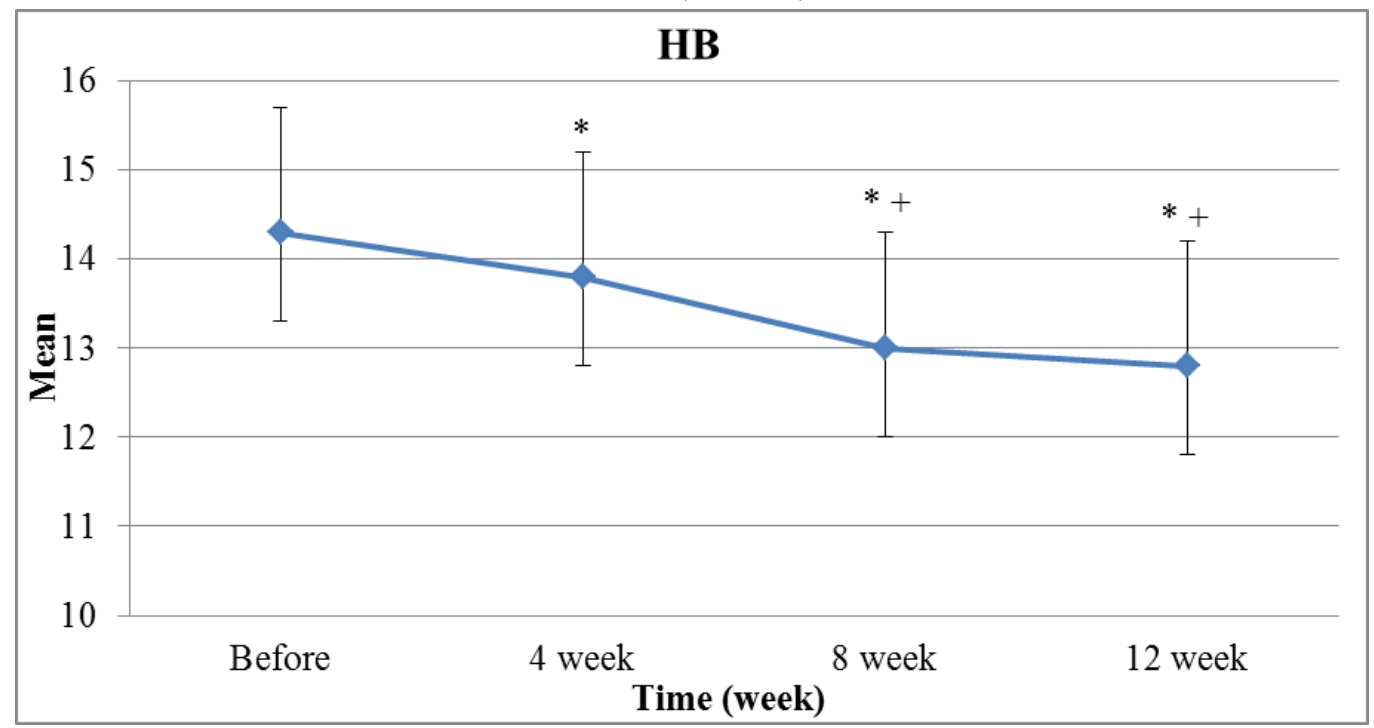

Figure (4b): Assessment of Hemoglobin percent of studied patients during different follow up period

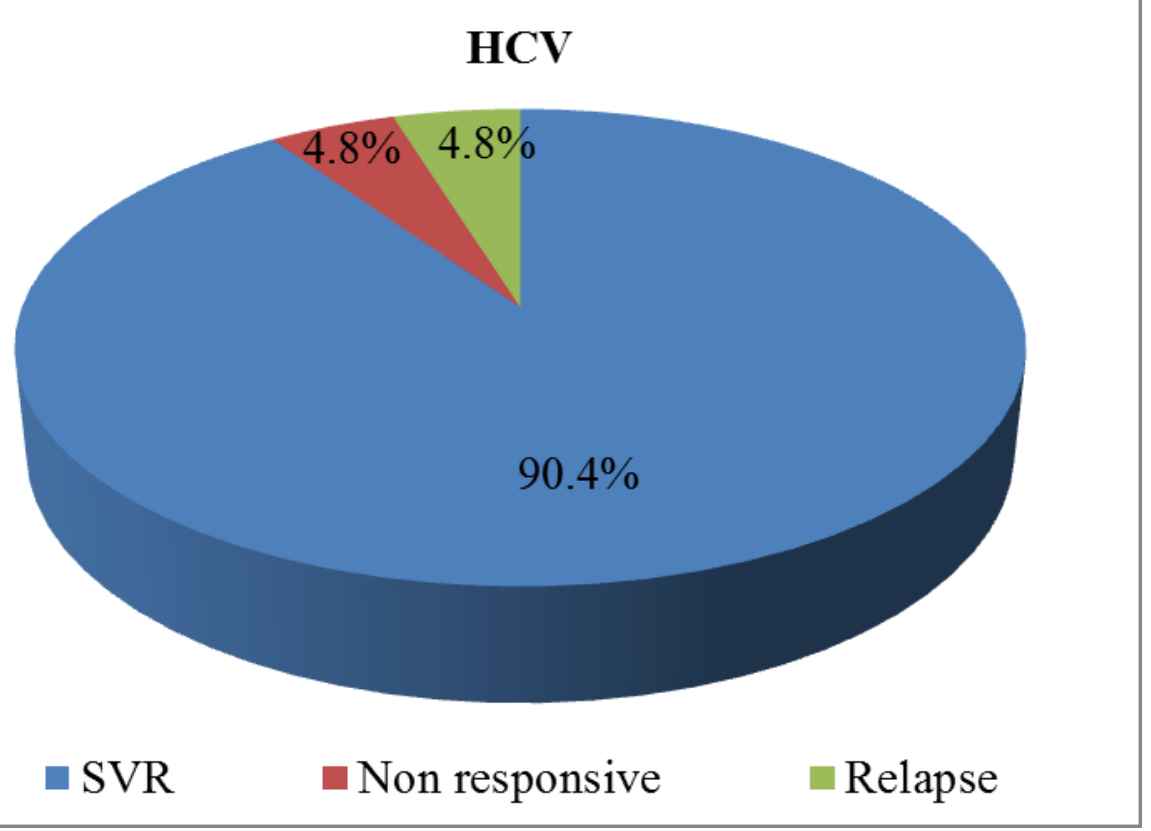

Figure 5 ) Assessment of efficacy of treatment

\section{Discussion}

Egypt ranks 5th amongst all countries for the burden of disease from viral hepatitis, HCV infects more than 170 million people worldwide. Over $80 \%$ of infected persons develop chronicity with increased potential to develop cirrhosis and HCC (Hanafiah etal.,2013).

Ages of the patients range from 36 to 72 years with mean age 53 years, $71 \%$ of patients were male and $28 \%$ of patients were females, $42 \%$ of patients were smokers and the major risk of transmission of $\mathrm{HCV}$ infection was antischistosomal injections in $42.9 \%$, Previous operations was a risk in $28.6 \%$ and there was no obvious risk in $28.6 \%$.

There was no symptoms suggestive of decompensated liver disease, by abdominal examination there was hepatomegaly in $42.9 \%$ and in $71.4 \%$ on ultrasonography. There was splenomegaly in $33.3 \%$ on ultrasonography.

there was no significant changes in pulmonary functions and chest imaging in studied patients 
before and after treatment which denotes safety of sofosbuvir and daclatasvir on respiratory system which goes with Dina etal., 2017.

Kohli et al. (2015) studied 20 patients with HCV infection. They were treat-ed by ledipasvir (90 $\mathrm{mg}$ ) and sofosbuvir (400 mg) as a single combination tablet once per day. Two patients (10\%) developed URTI.

Eric Lawitz Studied 20 patients founded that 2patients developed URTI and one patient developed bronchitis received Sofosbuvir plus ledipasvir for8 weeks.

in another study by Kao et al. (2016); 87 patients received treatment with sofosbuvir plus weightbased ribavirin for 12 weeks. URTI occurred in $16 \%(14 / 87)$ of patients.

fatiguability was the most frequent draw back and to less extent GIT toubles,cough and pruritus in about $4.8 \%$ of patients.

there was no significant change in Bilirubin, $\mathrm{PT}$ ,albumin , creatinine,WBC count platelets count and AFP during different weeks of treatment.

There was significant decrease of hemoglobin when compared before treatment and during different weeks of follow up.

There was significant normalization of liver enzymes when compared before treatment and during different weeks of follow up.

SVR was $90.4 \%$ non-responder was $4.8 \%$ and relapse was $4.8 \%$.

\section{References}

1. Waked I,GomaaA,Allam N etal.Hepatitis C infection in Egypt: prevalence, impact and management strategies Dove press journalHepatic Medicine: Evidence and Research 15 may 2017

2. AA Modi and TJ Liang. Hepatitis C: a clinical review oral Dis.2008 Jan; 14(1): 10-14.

3. HarmeetKaur Bhatia, Harmanjit Singh, NipunjotGrewaletal.Sofosbuvir: A novel treatment option for chronichepatitis C infectionjpharmacol,2013 IP: 197.39.40.174.

4. Osama

ashrafahmed,eslamsafwat,Mohamedomarkhalifa etal. sofosbuvir plus daclatasvir in treatment of chronic hepatitis $C$ genotype 4 infection in a cohort of Egyptian patients International journal of hepatology volume 2018.

5. Dina AbouelkheirAbdalla, Tamer Ali Elhadidy, TarekBesheeretal. Respiratory adverse effects of Sofosbuvir-based regimens for treatmentof chronic hepatitis $C$ virusEgyptian Journal of Chest Diseases and Tuberculosis 66 (2017) 363-367.

6. K.M. Hanafiah, J. Groeger, A.D. Flaxman, et al.,2013 Global epidemiology of hepatitis C virus infection: new estimates of age-specific antibody to HCV seroprevalence Hepatology 57 (2013) 1333-1342

7. Kohli, R. Kapoor, Z. Sims, et al.,2015 Ledipasvir and sofosbuvir for hepatitis $C$ genotype 4 : a proofof-concept, single-centre, open-label phase 2a cohort study. Lancet. Infect. Dis. 15 (2015) 10491054

8. Eric L, Fred F, Phillip S, Robert $H$, Xiao D, Hongmei Mo, William T, John G et-al.,2014 Sofosbuvir and ledipasvir fi xed-dose combination with and with-out ribavirin in treatment-naive and previously treated patients with geno-type 1 hepatitis $C$ virus infection Lancet. Infect. Dis. 2 (2014) 383: 515

9. H. Kao, R.N. Chien, T.T. Chang, et al.,2016 A phase $3 \mathrm{~b}$ study of sofosbuvir plus ribavirin in Taiwanese patients with chronic genotype 2 hepatitis C virus. infection, Liver Int. 36 (2016) 1101-1107 